\section{An Ecological Economics Perspective on Digitalisation}

\author{
By Tilman Santarius, Maike Gossen and Friederike Rohde
}

$T$ he various economic and social implications of "digitalisation" have been discussed in many scientific disciplines and regarding manifold aspects. For instance, early analyses on the digital economy began with Tapscott (1994) and Rochet and Tirole (2003), while publications on digital capitalism date from Schiller (1999) to Staab (2019).

Yet, ecological economy research has only marginally touched upon the issue of digitalisation so far. Despite a surge in publications regarding Green IT already in the 2000s and attempts to research ICT for Sustainability from a comprehensive and interdisciplinary perspective more recently, a particular focus on challenges related to governing economic activities linked to digitalisation in a way that these promote sustainability, is still emerging.

\section{Increased digitalisation}

This special issue wants to contribute to this endeavor. The articles combined in this volume all comprise interdisciplinary approaches that address the overarching questions that are key to ecological economics: How is the interdependence and coevolution of human economies and natural ecosystems affected by increased digitalisation? How can comprehensive governance arrangements and especially policies shape digitalisation in a sustainable way?

The publication appears timely, because the series of "Corona Shutdowns" in 2020 and 2021 have provided prime examples for this: As remote working from home, video conferencing, digital meetings and e-learning have greatly advanced due to politically imposed measures for social distancing, this has - at least intermittently - significantly reduced energy and resource consumption as well as greenhouse gas emissions from manufacturing, consumption and particularly, the transport sector. While it can be doubted whether such developments will last after the COVID-19-virus will be banned, the example highlights that the question whether digitalisation serves as a leverage or rather as an impediment to a sustainable economic transformation is of high relevance to ecological economy research.

\section{Bits \& Bäume}

The articles in this special issue ground in several years of public and science-policy debates in Germany. The research group Digitalization and Sustainability [1], which jointly conceptualized this journal issue, prepared the ground with some early events and publications, including the book Smart Green World (Lange/Santarius 2020). This significantly raised attention and fostered public debate on the issue, which achieved a first climax with the large networking conference Bits \& Bäume.

The conference brought together close to 2.000 civil society and scientific actors from the tech and "hacker" communities on the one hand, and the environmental and sustainability commu- nities on the other hand. The research group Digitalization and Sustainability continued this fruitful interdisciplinary networking by way of a public event series, the Forum Bits \& Bäume, throughout 2019 and 2021. The articles in this volume directly address the five topics of this event series and hence, provide insights not only from up-to-date research, but also incorporate ideas and feedback from transdisciplinary actors from policy and civil society which participated in the events.

\section{Annotation}

[1] The research group was established in 2016 as a cooperation project between the Institute of Ecological Economy Research (IÖW) and the Technical University Berlin.

\section{References}

Tapscott, D. (1994): The Digital Economy. Promise and Peril in The Age of Networked Intelligence. New York, McGraw-Hill.

Rochet, J.-C./Tirole, J. (2003): Platform Competition in Two-Sided Markets. Journal of the European Economic Association 1/4: 990-1029.

Schiller, D. (1999): Digital Capitalism. Networking the Global Market System. Cambridge, The MIT Press.

Staab, P. (2019): Digitaler Kapitalismus. Markt und Herrschaft in der Ökonomie der Unknappheit. Frankfurt, Suhrkamp.

Lange, S./Santarius, T. (2020): Smart Green World. Making Digitalization Work for Sustainability. Abbington, Routledge.

\section{AUTHORS + CONTACT}

Tilman Santarius is Professor of SocialEcological Transformation and Sustainable Digitalisation at the Technical University of Berlin and the Einstein Center Digital Futures.

Technical University of Berlin, Marchstraße 23, 10587 Berlin. E-mail: santarius@tu-berlin.de, Tel.: +493031478838

Maike Gossen and Friederike Rohde are researchers at the IÖW.

Institut für ökologische Wirtschaftsforschung (IÖW), Potsdamer Str. 105, 10785 Berlin. E-mail: maike.gossen@ioew.de, friederike. rohde@ioew.de, Tel.: +49308845940 de), which permits copying and redistributing the material in any medium or format, provided the original work is properly cited, it is not used for commercial purposes and it is not remixed, transformed or built upon. The access to the digital version of this article is reserved to subscribers of ÖkologischesWirtschaften until two years after the date of publication; after two years it is available to all readers. 